\title{
EXPRESSION OF MOUSE BETA DEFENSIN 2 IN ESCHERICHIA COLI AND ITS BROAD-SPECTRUM ANTIMICROBIAL ACTIVITY
}

\author{
Tianxiang Gong ${ }^{1}$, Wanyi $\mathrm{Li}^{2}$, Yueling Wang ${ }^{2}$, Yan Jiang ${ }^{2}$, Qiang Zhang ${ }^{2}$, Wei Feng ${ }^{1}$, Zhonghua Jiang ${ }^{2}$, Mingyuan Li ${ }^{2,3^{*}}$ \\ ${ }^{1}$ Chengdu Blood Centre, 610041 Chengdu, China; ${ }^{2}$ Department of Microbiology, West China School of Preclinical and Forensic \\ Medicine, Sichuan University, 610041 Chengdu, China; ${ }^{3}$ State Key Laboratory of Oral Diseases, Sichuan University, 610041 \\ Chengdu, China.
}

Submitted: October 23, 2009; Approved: March 14, 2011.

\begin{abstract}
Mature mouse beta defensin $2(\mathrm{mBD} 2)$ is a small cationic peptide with antimicrobial activity. Here we established a prokaryotic expression vector containing the cDNA of mature mBD2 fused with thioredoxin (TrxA), pET32a-mBD2. The vector was transformed into Escherichia Coli (E. coli) Rosseta-gami (2) for expression fusion protein. Under the optimization of fermentation parameters: induce with $0.6 \mathrm{mM}$ isopropylthiogalactoside (IPTG) at $34^{\circ} \mathrm{C}$ in $2 \times Y$ T medium and harvest at $6 \mathrm{~h}$ postinduction, fusion protein TrxA-mBD2 was high expressed in the soluble fraction (>95\%). After cleaved fusion protein by enterokinase, soluble mature $\mathrm{mBD} 2$ was achieved $6 \mathrm{mg} / \mathrm{L}$ with a volumetric productivity. Purified recombinant $\mathrm{mBD} 2$ demonstrated clear broad-spectrum antimicrobial activity for fungi, bacteria and virus. The MIC of antibacterial activity of against Staphylococcus aureus was $50 \mu \mathrm{g} / \mathrm{ml}$. The MIC of against Candida albicans (C. albicans) and Cryptococcus neoformans (C. neoformans) was $12.5 \mu \mathrm{g} / \mathrm{ml}$ and $25 \mu \mathrm{g} / \mathrm{ml}$, respectively. Also, the antimicrobial activity of $\mathrm{mBD} 2$ was effected by $\mathrm{NaCl}$ concentration. Additionally, $\mathrm{mBD} 2$ showed antiviral activity against influenza A virus (IAV), the protective rate for Madin-Darby canine kidney cells (MDCK) was $93.86 \%$ at the $\mathrm{mBD} 2$ concentration of $100 \mu \mathrm{g} / \mathrm{ml}$. These works might provide a foundation for the following research on the $\mathrm{mBD} 2$ as therapeutic agent for medical microbes.
\end{abstract}

Key words: Mouse beta defensin 2, Expression, Purification, Antimicrobial activity

\section{INTRODUCTION}

Defensins are cationic antimicrobial peptides that exert a direct antimicrobial effect on invading microbes and are expressed by many different organisms (1). They have broadspectrum antimicrobial activity against a variety of organisms including bacteria, fungi, and enveloped viruses (2). Based on the spatial distribution of their six-cysteine residues and the connectivity of the disulfide bonds, defensins can be classified into three categories: $\alpha$-, $\beta$-, and $\theta$-defensins (3). $\beta$-defensins are predominantly produced by barrier epithelial cells, they not only attack invading microbes, but may also modulate the

\footnotetext{
*Corresponding Author. Mailing address: Department of Microbiology, West China School of Preclinical and Forensic Medicine, Sichuan University, 610041 Chengdu, China.; Tel: +86-028-85501267.; E-mail: lmy3985@ sina.com
} 
host's immune response and cell-mediated immunity via cytokine expression, providing an interface between innate and adaptive immune response (4). With the growing problem of pathogenic organisms which are resistant to conventional antibiotics, there is increased interest in the pharmacological application of antimicrobial peptides to treat infection.

Especially, with the increasing of occurrence of immunocompromised patients and increasing use of catheters and implants, the incidence of invasive fungal infections in humans has increased considerably. Candida bloodstream infections have steadily increased since the 1980s and account for $8-15 \%$ of all bloodstream infections (5). It had initiated a search for innate peptide antibiotics as alternative drug therapies because of the presence of fungal strains with multidrug resistance. Mouse $\beta$-defensin 2 was firstly reported by Morrison et al. in 1999 (6), its gene sequence is similarly to another mouse and human airway beta defensins. In the past decade, the information on $\mathrm{mBD} 2$ function was very scarce, mBD2 was only reported to show activity against Staphylococcus aureus in vivo (7). The effects of mBD2 on pathogenic bacteria, fungi and virus had been poorly studied.

In the present paper, we established a prokaryotic expression system for producing recombinant mBD2 (rmBD2). The conditions of cultivation and induction were optimized systematically for further improve mBD2 productivity. Purified rmBD2 showed not only antibacterial activity against Staphylococcus aureus and antifungal activity against $C$. albicans and $C$. neoformans, but also antiviral activity against IAV. It might be as a therapeutic agent for the inhibition of microbe infection and avoiding the problems of acquired resistance.

\section{MATERIALS AND METHODS}

\section{Strain, medium, and enzyme}

E. coli JM109 was used as the host strain for gene manipulation. E. coli Rosseta-gami (2) (Novagen, Shanghai,
China) were used as host strains for fusion protein TrxAmBD2 expression. Staphylococcus aureus (ATCC 25923), Escherichia coli ATCC 25922, Pseudomonas aeruginosa (clinical isolate) were used for antibacterial assay. C. albicans (ATCC 10231) and C. neoformans (clinical isolate) were used for antifungal assay. IAV A/PuertoRico/8/34 (PR-8, H1N1) titer was determined by the $50 \%$ tissue culture infective does $\left(\mathrm{TCID}_{50}\right)$ analysis in MDCK and evaluated by the method of Reed and Muench.

Luria-Bertani (LB) medium (w/v), containing $0.5 \%$ yeast extract, $1 \%$ tryptone, and $1 \% \mathrm{NaCl}$, was used for manipulation of molecular clone, simple recombinant expression, and seed culture. $2 \times$ YT medium (w/v): $1.6 \%$ tryptone, $1 \%$ yeast extract, $0.5 \% \mathrm{NaCl}$, was used for fermentation. Mueller-Hinton broth (M-H medium) containing (w/v) $0.5 \%$ beef extract, $1.75 \%$ casamino acid, $0.15 \%$ starch was used for antibacterial assay. Sabouraud's medium (w/v), containing $1 \%$ peptone, $4 \%$ glucose and YPG medium (w/v) containing $1 \%$ yeast extract, $1 \%$ peptone, $2 \%$ glucose were used for antifungal assay.

Taq DNA polymerase, restriction enzymes, and T4 DNA ligase were purchased from Takara Biotech Co.Ltd (Dalian, China).

\section{Expression vector construction and protein expression}

The cDNA for mature mBD2 was amplified using polymerase chain reaction (PCR) from the pcDNA3.1(+)mBD2 plasmid, which was a gift from Dr. De Yang (NIH Senior Scientist, USA). Primers were designed according to the coding sequence of mBD2 (GenBank Accession No. AJ011800) and synthesized by Invitrogen (Shanghai, China), the forward primer: 5'-GCGGGTACCGACGACGACGACAA GGCAGAACTTGACCACTG-3', sequence containing a restriction site for Kpn I (underlined) and codons of enterokinase cleavage site (dotted) at the $5^{\prime}$ end; the reverse primer: 5'-GCGCTCGAGTCATTTCATGTACTTGCAACAG G-3', sequence containing a restriction site for Xho I (underlined) at the $5^{\prime}$ end. Standard molecular biology 
techniques were used in vector construction. The PCR conditions were following: $94^{\circ} \mathrm{C}, 4 \mathrm{~min} ; 30$ cycles of $94^{\circ} \mathrm{C}, 30 \mathrm{~s} ; 58^{\circ} \mathrm{C}, 30 \mathrm{~s}$; $72^{\circ} \mathrm{C}, 30 \mathrm{~s} ; 72^{\circ} \mathrm{C}, 5 \mathrm{~min}$. PCR product was cleaved by Xho I and Kpn I, and the mBD2 fragment was inserted into similarly digested pET32a(+) (Novagen, Shanghai, China) to construct the expression vector pET32a-mBD2. Vector pET32a-mBD2 was transformed into JM109 and the correct sequence was confirmed through DNA sequencing at the DNA sequencing laboratory of Takara Biotech Co. Ltd (Dalian, China). Vector pET32a-mBD2 was transformed into E.coli Rosseta-gami (2) for fusion protein expression. Isolated colonies were used to inoculate LB medium (containing $100 \mu \mathrm{g} / \mathrm{ml}$ ampicillin) overnight with shaking at $37^{\circ} \mathrm{C}$. Then, the overnight cell suspension was added to medium (with $100 \mu \mathrm{g} / \mathrm{ml}$ ampicillin) with the ratio of $1 \%(\mathrm{v} / \mathrm{v})$ at $37^{\circ} \mathrm{C}$ and cultured following the optimized condition: induce with $0.6 \mathrm{mM}$ IPTG at $34^{\circ} \mathrm{C}$ in $2 \times Y$ T medium, and harvest at $6 \mathrm{~h}$ post-induction. Each gram of cell paste was suspended in $10 \mathrm{ml}$ of binding buffer (20 mM sodium phosphate, $500 \mathrm{mM} \mathrm{NaCl}, 40 \mathrm{mM}$ imidazole, $\mathrm{pH}$ 7.4), which contains $1 \mathrm{mM}$ PMSF, and lyzed by sonication and subsequent centrifugation $12,000 \mathrm{rpm}$ for $25 \mathrm{~min}$ at $4^{\circ} \mathrm{C}$. The fusion protein was analyzed by $15 \%$ SDS-PAGE. The expression yield was analyzed using Quantity One Quantitation software (Bio-Rad) according to the relative band intensities of Coomassie blue staining.

\section{Product purification and analysis}

Purification was performed on the ÄKTA Purifer system (Amersham Pharmacia Biotech) with His Trap ${ }^{\mathrm{TM}}$ FF crude (GE, Healthcare), which was prepacked with the affinity medium $\mathrm{Ni}$ Sepharose 6 Fast Flow. The purified fusion protein (TrxA-mBD2) was desalted by Amicon ${ }^{\circledR}$ Ultra-15 10K Centrifugal Filter Devices (Millipore, USA) and subjected to recombinant Enterokinase-His (rEK-His, Zhongda Nanhai Marine Biotech, Guangdong, China) digestion at $25^{\circ} \mathrm{C}$ for $16 \mathrm{~h}$ in recommended buffer (0.2 mM Tris-HCl, $100 \mathrm{mM} \mathrm{NaCl}, \mathrm{pH} 8.0)$. The mixture buffer was further purified by His Trap $^{\mathrm{TM}} \mathrm{HP}$ crude. Released mature mBD2 peptide (theoretical molecular weight of $4.5 \mathrm{kDa}$ ) was obtained by the effluent of loading sample of digestion mixture and further desalted by Amicon ${ }^{\circledR}$ Ultra-15 3K Centrifugal Filter Devices. Finally, the released mature mBD2 was examined by Tricine-SDS-PAGE (8) and Western blot with anti-mBD2 antibody (Santa Cruz, CA, USA). The Bradford assay was used for quantitative analysis of protein.

\section{Antibacterial assay}

The antibacterial activity of $\mathrm{rmBD} 2$ was evaluated using a broth dilution assay (9). Bacterial organisms were grown overnight at $37^{\circ} \mathrm{C}$ with shaking in $\mathrm{M}-\mathrm{H}$ medium. The grown bacteria were inoculated into fresh broth and grown to mid-log phage. The grown bacteria were washed three times in $10 \mathrm{mM}$ sodium phosphate buffer ( $\left.\mathrm{PB}: \mathrm{Na}_{2} \mathrm{HPO}_{4} / \mathrm{NaH}_{2} \mathrm{PO}_{4}, \mathrm{pH} 7.5\right)$ and the final concentration was adjusted to $10^{4} \mathrm{cfu} / \mathrm{ml}$. $50 \mu \mathrm{l}$ grown bacteria and serial dilutions of $\mathrm{rmBD} 2$ in $\mathrm{PB}$ was added to each well of a microtiter plate, followed by incubation for $3 \mathrm{~h}$ at $37^{\circ} \mathrm{C}$. $100 \mu \mathrm{l}$ of $2 \times \mathrm{M}-\mathrm{H}$ medium was added to each well, and after $24 \mathrm{~h}$ of incubation at $37^{\circ} \mathrm{C}$, the MIC was determined by visual inspection and by measurement of the $\mathrm{OD}_{600}$. Various concentration of $\mathrm{NaCl}$ (from $0-150 \mathrm{mM}$ ) was used in the culture with $50 \mu \mathrm{g} / \mathrm{ml} \mathrm{rmBD} 2$ to analyze the effect of $\mathrm{NaCl}$ concentration on the antibacterial activity of against Staphylococcus aureus.

\section{Antifungal activity assays}

For MIC testing (10), fungal cells were grown in Sabouraud's medium and resuspended in the fresh yeast complete medium YPG with diluted 100-fold. The medium was dispensed by $90 \mu \mathrm{l}$ aliquots into the wells of a microplate containing $10 \mu \mathrm{l}$ of either $0.2 \mathrm{mM} \mathrm{NaHCO}_{3}$ or the twofold serial dilutions of rmBD2 or TrxA-mBD2 $(0.88-200 \mu \mathrm{g} / \mathrm{ml})$ in $0.2 \mathrm{mM} \mathrm{NaHCO}$. Growth of fungi was evaluated by visual analysis after $24 \mathrm{~h}$ at $30^{\circ} \mathrm{C}$.

Colony counting assay, concentration killing curve of rmBD2 was determined using colony counting assay (11) with slight modifications. Briefly, fungal cells were grown overnight in YPG medium. On the following day, the cells were washed three times in buffer $10 \mathrm{mM} \mathrm{PB}$ and the final concentration was adjusted to $1 \times 10^{6}$ cells $/ \mathrm{ml}$. The cell suspensions were mixed with serial dilutions of rmBD2 in $10 \mathrm{mM} \mathrm{PB}$ and incubated for $3 \mathrm{~h}$ at $37^{\circ} \mathrm{C}$. Cell suspensions were diluted 200 -fold in $10 \mathrm{mM} \mathrm{PB}$, followed by spread onto YPG agar plates and incubation at $25^{\circ} \mathrm{C}$. Control culture was incubated with $10 \mathrm{mM}$ PB alone. After $48 \mathrm{~h}$, fungal colonies were enumerated. Cell survival was expressed as a percentage of the control. Various concentration of $\mathrm{NaCl}$ (from 
0-150 $\mathrm{mM}$ ) was used in the culture with $25 \mu \mathrm{g} / \mathrm{ml} \mathrm{rmBD} 2$ to analyze the effect of $\mathrm{NaCl}$ concentration on the antifungal activity of against $C$. albicans and $C$. neoformans.

\section{Antiviral activity assay}

MTT assay was employed for evaluating the activity of rmBD2 against IAV [12]. Briefly, The PR-8 (10TCID $\left.{ }_{50}\right)$ were preincubated with serial double diluted rmBD2 or TrxA-mBD2 $(100-3.125 \mu \mathrm{g} / \mathrm{ml})$ in $10 \mathrm{mM}$ PB for $1 \mathrm{~h}$. The regular medium of confluent monolayer MDCK cells was aspirated and washed with PBS, followed by added the $100 \mu \mathrm{l}$ of the virus-peptide mixture to MDCK cells for $1 \mathrm{~h}$ at $37^{\circ} \mathrm{C}$. Cells were washed with PBS and overlaid with $100 \mu \mathrm{l}$ fresh DMEM medium. Tray was incubated at $37^{\circ} \mathrm{C}$ in $5 \% \mathrm{CO}_{2}$ for $48 \mathrm{~h}$ and cytotoxicity was measured with the MTT [3-(4,5-dimethylthiazolyl-2)-2,5-diphenyl tetrazolium bromide] kit (GMS10039, Genmed Scientifics Inc) following the manufacture's instructions.

\section{RESULTS AND DISCUSSION}

\section{Protein expression and purification}

Because of its well-established expression systems, fast growth rate and low cost, the E. coli is used commonly as a host cell to express proteins. In our present study, the employed expression system is the $E$. coli pET/Origami, in which the $E$. coli Origami host strains have mutations in both the thioredoxin reductase and the glutathione reductase genes to enhance greatly cytoplasmic disulfide bond formation (13). Additionally, the Rosseta strains supply rare tRNAs to enhance the expression of eukaryotics proteins. In the expression vector pET32a-mBD2 (Figure 1), mBD2 was fused with TrxA, this fusion expression alleviates the obstacles in using $E$. coli as the host cell for antibiotic peptides expression, including the host-killing activity and the susceptibility to degradation of product (14). Between the TrxA and mBD2 coding sequence, there is a His.Tag, which serves as the detection and purification tag in later steps. This expression vector was transformed into E. coli Rosetta-gami (2) for expression fusion protein. In SDS-PAGE analysis, compared to the negative control of Rosseta-gami(2)/pET32a, a foreign protein was expressed in Rosetta-gami(2)/pET32a-mBD2. Under the optimization of fermentation parameters, the fusion protein TrxAmBD2 reached $95 \%$ in the soluble fraction (Figure 2a). The rEKHis cleaved fusion protein was further purified by His Trap ${ }^{\mathrm{TM}} \mathrm{HP}$ crude, and the mature mBD2 was released by the precise cleavage of TrxA-tag. The mBD2 was analyzed by Tricine-SDS-PAGE (Figure 2b) and Western blot. Finally, the expression of soluble mature mBD2 was achieved $6 \mathrm{mg} / \mathrm{L}$ with a volumetric productivity.

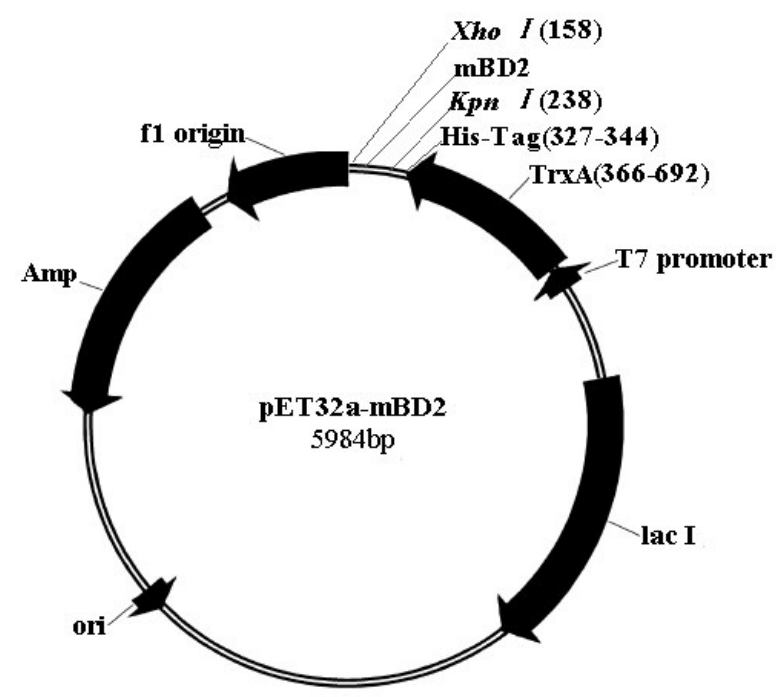

Figure 1. Schematic representation of the expression vector, pET32a-mBD2. The cDNA for mature mBD2 were amplified using PCR from the pcDNA3.1(+)-mBD2 plasmid. PCR product was cleaved by Xho $I$ and Kpn I, and the mBD2 fragment was inserted into similarly digested $\mathrm{pET} 32 \mathrm{a}(+)$ vector to construct the expression vector, pET32a-mBD2.

a

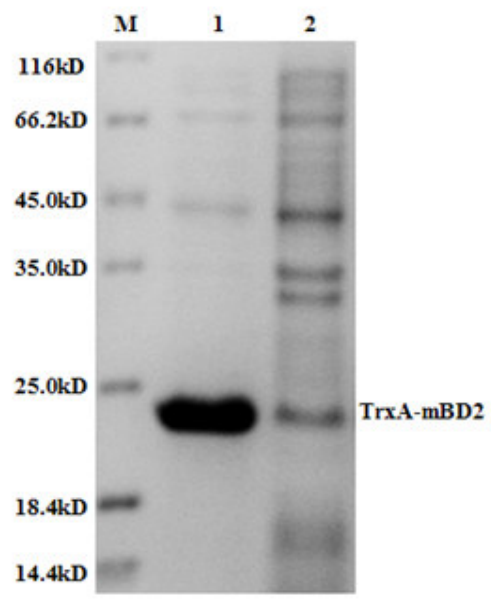




\section{b}

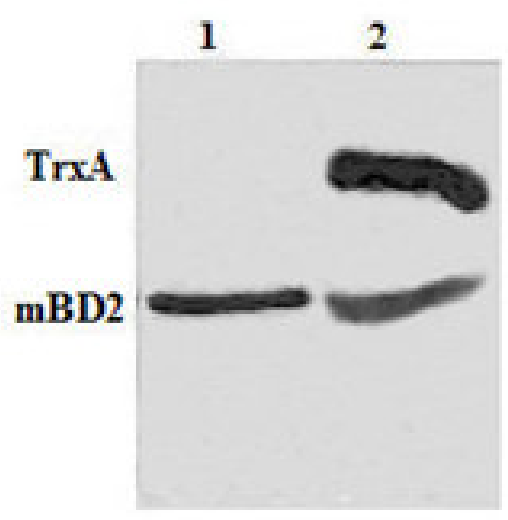

Figure 2. Expression of fusion protein TrxA-mBD2 in E. coli Rosseta-gami (2)/pET32a-mBD2 cells and Tricine-SDS-PAGE analysis of enterokinase digested. The cDNA for mature mBD2 was inserted into pET32a(+) to construct the expression vector pET32a-mBD2, which was transformed into E. coli Rossetagami (2) for expression fusion protein. (a) Fusion protein was expressed in soluble and insoluble forms. Under the optimization of fermentation parameters: induce with $0.6 \mathrm{mM}$ IPTG at 34 in the 2xYT medium and harvest at $6 \mathrm{~h}$ postinduction, fusion protein TrxA-mBD2 was high expressed in the soluble fraction (>95\%). Lane 1: soluble protein of Rossetagami (2)/pET32a-mBD2; Lane 2: insoluble protein of Rossetagami (2)/pET32a-mBD2; (b) The fusion protein was specifically digested with rEK-His, the mixture buffer was further purified by His Trap ${ }^{\mathrm{TM}} \mathrm{HP}$ crude. The released mature rmBD2 protein was obtained by the effluent of loading sample of digestion mixture and further desalted and condensed by Amicon ${ }^{\circledR}$ Ultra-15 3K Centrifugal Filter Devices. Lane 1: purified mature mBD2; Lane 2: mixture of TrxA-mBD2 after rEK-His digestion.

\section{Antibacterial assay}

The result of broth dilution assay showed that MIC value of rmBD2 against Staphylococcus aureus was $50 \mu \mathrm{g} / \mathrm{ml}$, and the concentration killing curves was shown in Figure 3a. The growth of Staphylococcus aureus was strongly suppressed with the increasing concentration of $\mathrm{rmBD} 2$. Thus, the rmBD2 showed antibacterial activity against Staphylococcus aureus. This result was in accordance with antibacterial assay of mBD2 in vivo (7). However, the antibacterial activity of rmBD2 against E. coli and Pseudomonas aeruginosa was not observed at the concentrations of $0.88-200 \mu \mathrm{g} / \mathrm{ml}$ (data not shown). In addition, the result of the effect of $\mathrm{NaCl}$ concentration on the antibacterial activity of $\mathrm{mBD} 2$ showed that $\mathrm{mBD} 2$ is a saltsensitive peptide (Figure 3b). So far, most defensins and other antimicrobial peptides were described $(15,16)$ as the saltsensitive peptides, sodium chloride inhibited the antimicrobial activity. Tomita et al. (17) reported other salts with similar effects and a higher strength, not the specific ions are the cause of the inhibition. Currently, disruption of the initial interaction between the negatively charged membrane of microbe and the positively charged peptide is thought to be the cause of this dependency of ionic strength on activity (18).

\section{Antifungal assays}

Because of the toxicity of the currently used polyene antifungal drugs and the emergence of resistant candidal specie to azolebased agents, alternative treatment strategies are needed. Due to their unique mechanism of action, $\beta$-defensins are expected to be ideal therapeutic agents for mitigating the problem of acquired resistance (19). Several plant defensins are inhibitory to $C$. albicans which can cause fatal infections in immunocompromised patients (20). In the present work, two assays were employed to examine the antifungal activity of mBD2. The results of MICs determination assay showed activity against $C$. albicans and $C$. neoformans with MIC 12.5 $\mu \mathrm{g} / \mathrm{ml}$ and $25 \mu \mathrm{g} / \mathrm{ml}$, respectively. It should be noted that the value of MIC is also affected by assay conditions such as initial concentration of fungal cells, used medium, and the incubation time, etc. The concentration killing curves of rmBD2 were determined by colony counting assay, and the 
results were shown in Figure 4a. The growth of $C$. albicans and $C$. neoformans were significantly suppressed with the increasing concentration of rmBD2. Thus, our results suggest that mBD2 would play a role in the protection of fungal infection. However, the antimicrobial activity of fusion protein TrxA-mBD2 was not observed at the concentrations $0.88-200 \mu \mathrm{g} / \mathrm{ml}$ (data not shown).
In addition, the $\mathrm{NaCl}$ concentration also had an effect on the antifungal activity of mBD2. And the antifungal effect was suppressed by increasing $\mathrm{NaCl}$ concentration, when the concentration was $150 \mathrm{mM}$, rmBD2 was almost totally inactive (Figure 4b). This salt-sensitive property was in accordance with another peptides isolated from mouse $(9,16)$.
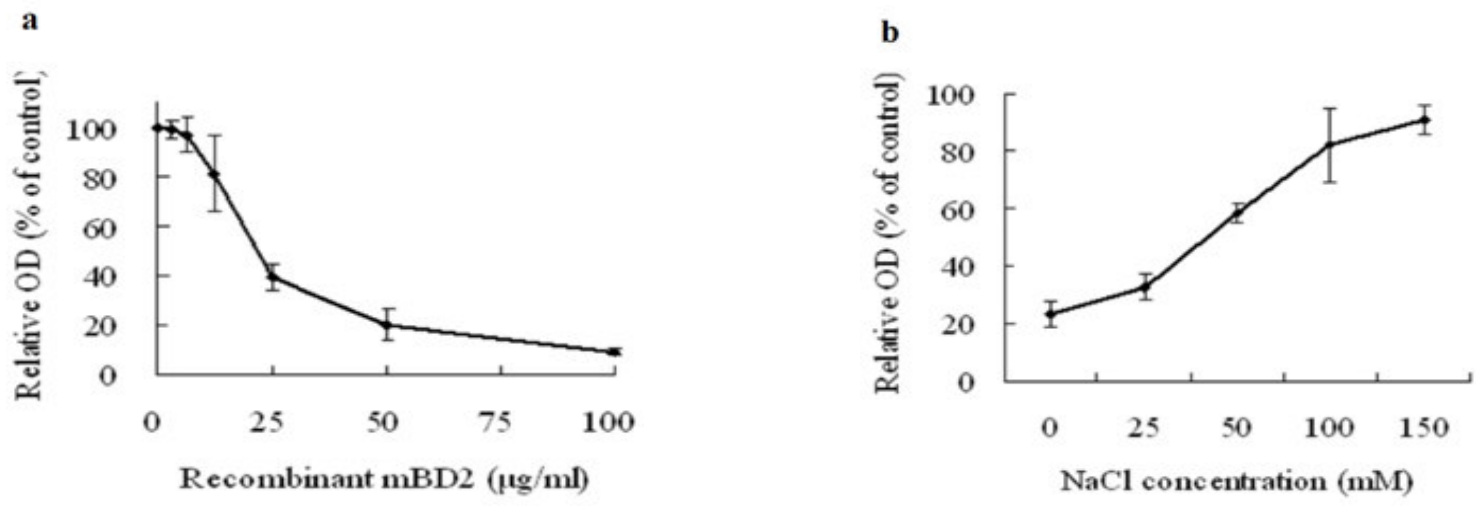

Figure 3. Antibacterial activity of rmBD2 using the broth dilution assay. Bacterial cells were inoculated into fresh broth and grown to mid-log phage. The cells were washed three times and the final concentration was adjusted to $10^{4} \mathrm{cfu} / \mathrm{ml} .50 \mu 1$ cells and serial dilutions of rmBD2 in 10 $\mathrm{mM}$ PB were added to each well of a microtiter plate, followed by incubation for $3 \mathrm{~h}$ at $37^{\circ} \mathrm{C} .100 \mu \mathrm{l}$ of $2 \times \mathrm{M}-\mathrm{H}$ medium was added to each well, and after $24 \mathrm{~h}$ of incubation at $37^{\circ} \mathrm{C}$, the cells growth was determined by visual inspection and by measurement of the $\mathrm{OD}_{600}$. Bacterial growth is expressed as percentage of maximal OD observed in the absence of peptide. $0-150 \mathrm{mM} \mathrm{NaCl}$ were used in the culture with $50 \mu \mathrm{g} / \mathrm{ml} \mathrm{rmBD} 2$ to analyze the effect of $\mathrm{NaCl}$ concentration on the antibacterial activity. (a) Bacterial-killing curve of rmBD2 against Staphylococcus aureus. (b) Effect of $\mathrm{NaCl}$ concentration on rmBD2 against Staphylococcus aureus. Data was obtained from three independent experiments performed each in triplicate and reported as mean \pm standard deviation.
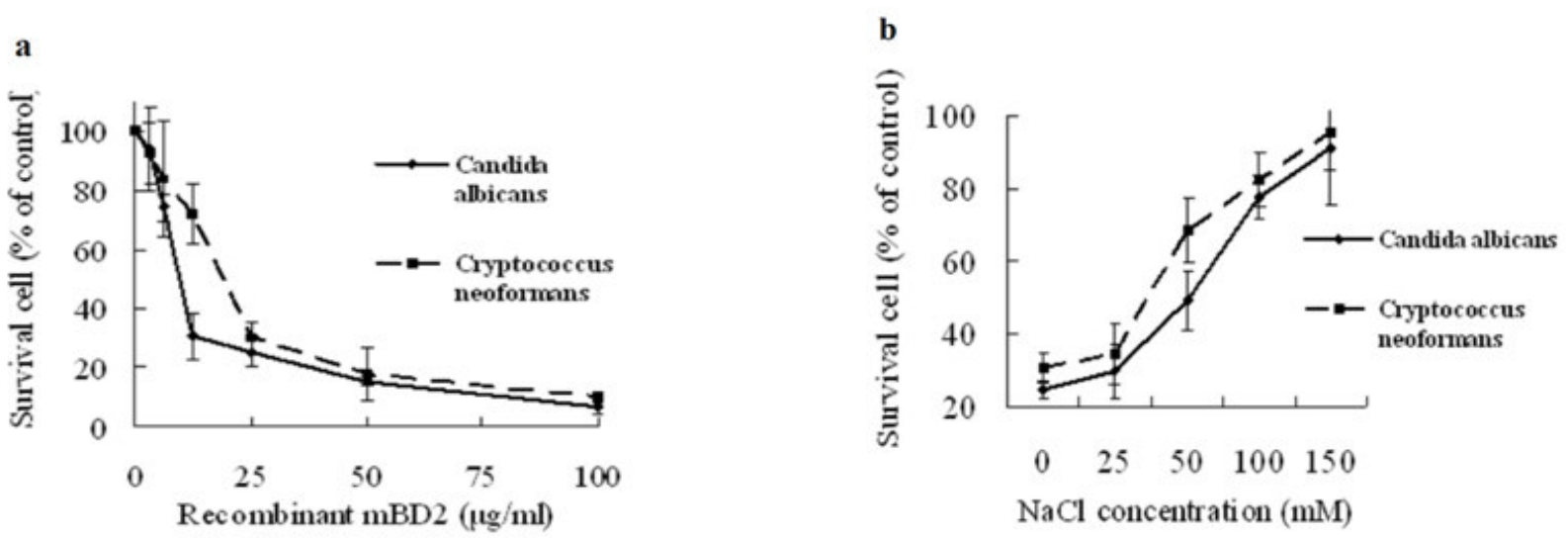

Figure 4. Antifungal activity of $\mathrm{rmBD} 2$ using the colony counting assay. Fungal cells were grown overnight in medium YPG. The cells were washed three times in buffer $10 \mathrm{mM}$ PB and the final concentration was adjusted to $1 \times 10^{6}$ cells $/ \mathrm{ml}$. The cell suspensions were mixed with serial dilutions of rmBD2 in $10 \mathrm{mM}$ PB and incubated for $3 \mathrm{~h}$ at $37^{\circ} \mathrm{C}$. Cell suspensions were diluted 200 -fold in $10 \mathrm{mM}$ PB, followed by spread onto YPG agar plates and incubation at $25^{\circ} \mathrm{C}$. Control culture was incubated with $10 \mathrm{mM} \mathrm{PB}$ alone. After $48 \mathrm{~h}$, fungal colonies were enumerated. 0-150 $\mathrm{mM} \mathrm{NaCl}$ were used in the culture with $25 \mu \mathrm{g} / \mathrm{ml} \mathrm{rmBD} 2$ to analyze the effect of $\mathrm{NaCl}$ concentration on the antifungal activity of against $C$. albicans and C. neoformans. (a) Fungal-killing curve. (b) Effect of $\mathrm{NaCl}$ concentration on the antifungal activity of rmBD2. Data was obtained from three independent experiments performed each in triplicate and reported as mean \pm standard deviation. 


\section{Antiviral activity assay}

In addition to the antibacterial and antifungal activity, antiviral activity of mBD2 was assessed against IAV. MDCK cells were incubated with serial double diluted rmBD2-treated PR-8, and the cytotoxicity was evaluated at $48 \mathrm{~h}$ postinfection with MTT kit. Under presented conditions, rmBD2 was effective to protect MDCK from infected with PR-8 and decreased virus-induced cell death in a dose-dependent manner (Fig.5) (12). The protective rate was $93.86 \%$ at the rmBD2 concentration of $100 \mu \mathrm{g} / \mathrm{ml}$. However, the fusion protein TrxAmBD2 had no activity of anti-influenza (data not shown). It suggested that rmBD2 has the clear antiviral activity.

In conclusion, firstly, we successfully established a highlevel expression system of functional mBD2 peptide, this protocol could be applied for design and expression of other functional antimicrobial peptides. Secondly, this work firstly demonstrated that mBD2 exhibits broad-spectrum antimicrobial activity. It showed not only strongly antibacterial and antifungal activities but also antiviral activity. It may play an important role in the innate immune response against these pathogens in the airway of mice. Its pharmaceutical potential and medical importance are worth further exploring.



Figure 5. Antiviral activity of rmBD2 using the MTT assay. The viruses were preincubated with different concentrations $(100-3.125 \mu \mathrm{g} / \mathrm{ml})$ of $\mathrm{rmBD} 2$ for $1 \mathrm{~h}$ at $37^{\circ} \mathrm{C}$, followed by added the virus-peptide mixture to confluent monolayer
MDCK cells for $1 \mathrm{~h}$ at $37^{\circ} \mathrm{C}$. Infection mixture was discarded and cells were washed with PBS and overlaid with fresh DMEM. The cytotoxicity was measured with the MTT kit after infected $48 \mathrm{~h}$. The percentage of antiviral activities of the rmBD2 was calculated as: protective rate $=[$ (mean optical density of test - mean optical density of virus controls)/(optical density of cell controls - mean optical density of virus controls)] $\times 100 \%$. At the concentration 100 $\mu \mathrm{g} / \mathrm{ml}$, rmBD2 protected $93.86 \%$ cells from infection by influenza virus PR-8 (12).

\section{ACKNOWLEDGEMENTS}

We are deeply grateful to Dr. De Yang for the gift of pcDNA3.1(+)-mBD2. This work was financially supported by National Natural Science Foundation of China (No. 30671964, People's Republic of China).

\section{REFERENCE}

1. Bals, R.; Wang, X.; Wu, Z.; Freeman, T.M.; Bafna, V.; Zasloff, M.; Wilson, J.M. (1998). Human beta-defensin 2 is a salt-sensitive peptide antibiotic expressed in human lung. J. Clin. Invest. 102, 874-880.

2. Bals, R.; Goldman, M.J.; Wilson J.M. (1998). Mouse beta-defensin 1 is a salt-sensitive antimicrobial peptide present in epithelia of the lung and urogenital tract. Infect Immunol. 66 (3), 1225-1232.

3. Berrouane, Y.F.; Herwaldt, L.A.; Pfaller, M.A. (1999). Trends in antifungal use and epidemiology of nosocomial yeast infections in a university hospital. J Clin Microbiol. 37 (3), 531-537.

4. Bessete, P.H.; Aslund, F.; Beckwith, J.; Georgiou, G. (1999). Efficient folding of proteins with multiple disulfide bonds in the Escherichia coli cytoplasm. Proc Nat Acad Sci. 96 (24), 13703-13708.

5. Burd, R.S.; Furrer, J.L.; Sullivan, J.; Smith, A.L. (2002). Murine Beta defensin 3 is an inducible peptide with limited tissue expression and broad-spectrum antimicrobial activity. SHOCK. 18 (5), 461-464.

6. De Smet, K.; Contreras, R. (2005). Human antimicrobial peptides: defensins, cathelicidins, and histatins. Biotechnol Lett. 27 (18), 13371347.

7. Edwin J.A.; Veldhuizen, M.R.; Erwin, A.C.; van Dijk, A.; Henk, P.H. (2008). Procine $\beta$-defensin 2 displays broad antimicrobial activity against pathogenic intestinal bacteria. 45, 386-394.

8. Epand, R.M.; Vogel, H.J. (1999). Diversity of antimicrobial peptides and 
their mechanisms of action. Biochim Biophys Acta. 1462 (1-2), 11-28.

9. Ganz, T. (2003). Defensins: antimicrobial peptides of innate immunity. Nat Rev Immunol. 3 (9), 710-720.

10. Gong, T.X.; Jiang, Y.; Wang, Y.L.; Yang, D.; Li, W.Y.; Zhang, Q.; Feng, W.; Wang, B.N.; Jiang, Z.H.; Li, M.Y.. (2010). Recombinant mouse beta-defensin 2 inhibits infection by influenza A virus by blocking its entry. Arch Virol. 155: 491-98.

11. Hobson, R.P. (2003). The global epidemiology of invasive Candida infections-is the tide turning? J Hosp Infect. 55 (3), 159-168.

12. Hussain, T.; Nasreen, N.; Lai Y.M.; Bellew, B.F.; Antony, V.B.; Kamal A. Mohammed, K.A. (2008). Innate immune responses in murine pleural mesothelial cells: Toll-like receptor-2 dependent induction of betadefensin-2 by staphylococcal. Am J Physiol-lung Cell Physiol. 295 (3), 461-470.

13. Lehrer, R.I. (2004). Primate defensins. Nat Rev Microbiol. 2 (9), $727-$ 738.

14. Morrison, G.M.; Davidson, D.J.; Dorin, J.R. (1999). A novel mouse beta defensin, Defb2, which is upregulated in the airways by lipopolysaccharide. FEBS Lett. 442 (1), 112-116.
15. Piers, K.L.; Brown, M.H.; Hancock, R.E.W. (1993). Recombinant DNA procedures for producing small antimicrobial cationic peptides in bacteria. Gene. 134, 7-13.

16. Schagger, H.; Jagow, G.V. (1987). Tricine-sodium dodecyl sulfatepolyacrylamide gel electrophoresis for the separation of proteins in the range from 1 to $100 \mathrm{kDa}$, Anal Biochem. 166 (2), 368.-379.

17. Shafer W.M. (1997). Methods in Molecular Biology: Antibacterial Peptide Protocols. Vol. 78. Totowa, NJ. Humana Press Inc. p, 35-48.

18. Tomia, T.; Hitomi, S.; Nagase, T.; Matsui, H.; Kimura, S.; Ouchi, Y.; (2000). Effect of ions on antibacterial activity of human beta defensin 2 . Microbiol. Immunol. 44, 749-754.

19. Vylkova, S.; Li, X.S.; Berner J.C.; Edgerton, M. (2006). Distinct antifungal mechanisms: B-Defensins require Candida albicans Ssa1 Protein, while Trk1p mediates activity of cysteine-free cationic peptides. Antimicrob Agents Chemother. 50 (1), 324-331.

20. Yang, D.; Liu, Z.H.; Tewary, P.; Chen, Q.; de la Rosa, G.; Oppenheim, J.J. (2007). Defensin participation in innate and adaptive immunity." Currt Pharm Design. 13 (30), 3131-3139. 